\title{
The Entry of Brazilian Fresh Fruit Small and Medium Producers Into the Global Market
}

\author{
Roberta de Castro Souza ${ }^{1}$ \\ João Amato Neto ${ }^{2}$
}

\begin{abstract}
The objective of this paper is to identify some elements which contribute to the entry of small and medium producers into the global market. Specifically, it analyses the case of the greatest Brazilian mango and grape exported region - the Petrolina-Juazeiro (P-J). The conceptual background consists of two approaches. The first conceptual framework is the Global Value Chain (GVC) approach which is mainly concerned with the entry of local economies, from developing countries, into the global market. The second approach is the dynamic capability which is mainly concerned with the way the firm could acquire capabilities. The method selected for the empirical part was the multiple-case studies which were made viable by means of semi-structured questionnaires conducted with mango and grape producer agents from P-J Region in Brazil and European buyers. This study indicates that some institutions have been supporting the export activities in terms of irrigation techniques, new techniques of cultivation, financial support and the introduction of some certificates such as EurepGap. Lastly, the mango and grape producers have been undertaking upgrading of product, process and functional.
\end{abstract}

Key-words: Global chain; upgrading; capabilities.

Resumo: $O$ objetivo deste artigo foi identificar os elementos que contribuem para a entrada de pequenos e médios produtores no mercado global. Especificamente foi analisado o caso da maior região brasileira exportadora de manga e uva in natura, a de Petrolina (PE) e Juazeiro (BA). Os aportes teóricos utilizados neste artigo foram: cadeia de valor global e capacitações dinâmicas. O método selecionado para a realização da parte empírica foi o estudo de casos múltiplos. Para a coleta de dados, foram elaborados

1 Professora Doutora do Departamento de Engenharia de Produção, Escola Politécnica. Universidade de São Paulo (USP). E-mail: robertacsouza@usp.br

2 Professor Titular do Departamento de Engenharia de Produção, Escola Politécnica. Universidade de São Paulo (USP). E-mail: amato@usp.br 
questionários semi-estruturados e realizadas entrevistas presenciais com produtores de manga e uva, associações de produtores, instituições de apoio localizadas em Petrolina e Juazeiro e compradores europeus de manga e uva. O estudo indicou que algumas instituições vêm apoiando o desenvolvimento da região no que tange as exportações de manga e uva principalmente transferindo conhecimento sobre padrões de qualidade dos mercados consumidores internacionais.

Palavras-chave: cadeia de valor; upgrading; capacitações.

Classificação JEL: Q17.

\section{Introduction}

In general one of the main tendencies in global agriculture is the exclusion of small and medium producers from the global market (GARCIA \& POOLE, 2004; VORLEY, 2003) Some elements have been contributing to this process such as the concentration of retail sector and the huge increase in quality requirements in developed countries. These impose high costs for small and medium producers in order to meet the requirements (VORLEY, 2003). Therefore, it is important to identify the agents and actions which could support the entry of small and medium producers into the external market.

In these terms some questions raised. The first one is: How could local producers acquire capabilities for meeting the requirements of the external market? The second one is: What kind of agents and institutions are involved in this process? The third one is: What kind of upgrading the local producers could carry out? And finally: When producers are organized in networks how do they acquire capabilities?

In this paper two approaches are used to investigate the case of the largest Brazilian mango and grape exported region, the Petrolina-Juazeiro region located in the Northeast of Brazil. The first one is the Global Value Chain whose main concern is the entry of small and medium producers into the global market and the investigation of some aspects of this phenomenon such as governance, the level and kind of upgrading undertaking by local producers and the importance of institutions supporting the actions of small and medium producers (GEREFFI, 1999; HUMPHREY; SCHMITZ, 2000).

The second one is the Dynamic Capabilities approach which is in the field of strategic management and the main concern is to understand the sources of competitive advantage. Three elements are fundamental in this approach. The first one is the routines of the firm. Through its routines the firm could achieve competitive advantage. The second point is the history of the firm, called path dependency. The third point is the importance of the environment affecting the 
firm activities. The firm must adapt its internal and external skills in line with the environment changes (TEECE, PISANO, 1994; TEECE, PISANO, SCHUEN, 1997, WINTER, 2005). This paper is structured in five parts. The first one presents the two approaches used to explain the phenomenon, Global Value Chain and Dynamic Capabilities and the relations between them in order to analyse the empirical part followed by methodology section. The third part shows the main European Union requirements for the import of fresh fruits and the explanation about Petrolina-Juazeiro region. After this we present the methodology, the Integrated Fruit System, the description of relationships between PJ producers and European buyers, the discussion of results, and conclusion.

\section{Conceptual Framework}

\subsection{Global Value Chain approach (GVC)}

The first conceptual framework is the Global Value Chain approach (GEREFFI, 1999) which is mainly concerned with the entry into the global market of local economies from developing countries. In this approach it is important to consider some elements such as the governance power from different sectors which constitute the production chain, the challenges of local agents in order to meet the requirements of the global market and the concept of upgrading and value chain.

According to Kaplinsky, Morris (2001) a production chain could be called value chain. A value chain

describes the full range of activities which are required to bring a product or service from conception, through the different phases of production (involving a combination of physical transformation and the input of various producer services), delivery to final consumers, and final disposal after use (KAPLINSKY \& MORRIS, 2001, p.4).

In this article, a value chain is formed by input industry agents, producer agents, industry agents (responsible by the transformation of the product), distributive agents and the final consumer. Each agent is responsible for adding value to the final product. Then, the final product conditions depend on the action of each agent. Moreover, the relations between agents are usually unequal and some agents have more power than others. Nowadays, in most food production chains the retail agents are driving activities of other segments and define patterns for other agents in some food chains (DOLAN \& HUMPHREY, 2000; REARDON et al, 2003).

The concept of upgrading is related to the idea of innovation, according to Schumpeter. For him, innovation may be interpreted as new consumer goods, the production or transport methods, the exploration of new markets, and new forms of industrial organization. As for Humphrey, Schmitz (2000), innovation 
can be called upgrading, that is, it consists of making products in a more efficient way, adding value to products, making goods and processes more sophisticated. Also, according to the authors, upgrading can be of three types. Firstly, process, when reorganizing the production system or when using a new technique, this causes the process to be more efficient; Secondly, product, deriving from the manufacture of products with higher added value; and finally, functional, deriving from new functions that the firm may have along the chain, such as design or marketing. Having in mind the upgrade idea, Humphrey, Schmitz (2000) introduce the importance of organizations or clusters of organizations in developing countries of being inserted into global markets. According to the authors, the insertion of these organizations in the international context depends on the upgrading they have attained. This innovation may be directly related to the global norms that have encouraged local systems to adapt to the new specifications. However, for innovation to happen it is also fundamental to create a set of rules in the local environment to encourage it. This set of rules may be set by public initiative, private or both. This set of rules is denominated governance, and public and private governance play a fundamental role for fostering local conditions for fostering upgrade.

The concept of governance is linked to the agents' power in the value chain. According to Humphrey, Schmitz (2000, p. 20), the term governance express "that some firms in the chain set and/or enforce the parameters under which others in the chain operate". According to Gereffi (1999), when the buyer exerts a certain control over the chain, that is, determining certain rules for other agents to act, this is called "buyer driven" governance (HUMPHREY \& SCHMITZ, 2001; SCHMITZ \& KNORRINGA, 2000).

The GVC have been used to investigate different cases of producers from developing country in their action into the external market such as garment industry (GEREFFI, 1998), fresh fruit and vegetables (DOLAN \& HUMPHREY, 2000) the production and exports of leather shoes in Brazil (SCHMITZ, 1998). Besides, there are some studies about networks and cooperation and the entry of network of producers, such as clusters, into the global market (SCHMITZ, 1998; SAUVÉE, 2001; LAZZARINI et al, 2001; ZYLBERSZTAJN \& NADALINI, 2007). However, the aim of this study is just identify the main requirements of European markets and some actions undertake by producers in PJ in order to meet these requirements.

\subsection{Dynamic Capability Approach}

This approach is part of the field of strategic management and the main concern is to understand the sources of competitive advantage. Capabilities "emphasizes the key role of strategic management in appropriately adapting, integrating, and re-configuring internal and external organizational skills, resources, and functional competences towards changing environment" (TEECE 
\& PISANO, 1994). The term dynamic is linked to the environment which is changing all the time. The firm must be dynamic in order to adjust.

There are some elements which contribute to determine the dynamic capabilities of the firm and consequently its competitive advantage. They are processes, positions and paths. The first one is the routines of the firm, the ways that the processes are conducted, such as the managerial and organizational processes. The second element, positions, is linked to business assets which encompass the plant, equipment, and relational aspects. The third element is the path which involves the history of the firm and its background. Indeed, the author points out the importance of the firm history. Each firm has some history and in this process they can learn and accumulate some knowledge. This background is fundamental to determining the competitive position of the firm in the present and future, called path dependency (DAVID, 2007). For this paper it is necessary to underline the importance of the routines as a way of learning. The second aspect is the importance of internal and external capabilities. The external capabilities could be acquired through the relationships between firms and suppliers, buyers, and institutions. In addition to this, some routines attributed to local or regional factors could support and influence the firms in the early stages (TEECE \& PISANO, 1994; LALL, 1992). According to Lundvall (1992) the firm could acquire knowledge through its surroundings.

In this paper, the main idea is to relate the concepts of capabilities and upgrading. Based on the literature presented, the capabilities are divided in two groups, technical and market. The first implies all the knowledge of the firm about how to produce and to meet the requirements imposed by certificates such as EurepGap. This one is related to process and product upgrading. The market capabilities involve the knowledge about new markets and the action in other segment of the value chain. This one can be related to the functional and inter-sector upgrading (TEECE, PISANO \& SCHUEN, 1997). It is important to point out that the focus of GVC is the chain and the entry of producers from developing countries into the global market. In the case of DC the main concern is the management of the firm and their action.

\section{Method}

The field research is based on secondary and primary data. The secondary data was obtained from reports of research conducted in the Petrolina-Juazeiro region about fresh fruit production and exports, articles and data base about trade flow. Regarding the primary data it was used a qualitative approach and the method selected was the multiple-case studies (YIN, 2001; EISENHARDT, 1989). It is investigated the production segment of two fresh fruits, mango and grape. The multiple-case studies method was made viable by means of semi- 
structured questionnaires conducted with mango and grape producer agents from Petrolina-Juazeiro region (P-J) in Brazil and European mango and grape buyers located in the United Kingdom, the Netherlands and the Germany. The primary data was collected in 2004 and 2005, and it was conducted in depth-interviews with 11 European importers of fresh fruit from Brazil located in Germany, England and Netherlands. It was also interviewed English wholesalers located in Spitafields one of the biggest fresh fruit trade market in London. In Brazil, it was carried out in depth-interviews with 16 experts (research institutions, association of producers and exporters, and producers). The interviews were conducted with individual firms based on the literatures previously reviewed. The categories of analysis considered on this study are: the routines for acquiring capabilities, path dependency which is related to the learning process of the organization and its history, and the environment which refers to the links to institutions and other agents.

\section{European requirements for fresh fruit imports}

According to Vorley (2003) in the process of the retail sector concentration it is possible to point out some elements such as: absolute costs and barriers to entry for competitors are rising; own label branding; supply relationships with preferred suppliers and increasing in requirements such as certificates.

As was said in the previous paragraph one of the main strategies of supermarket sector is to keep close relations with a small number of suppliers. In this process they transfer a group of activities to suppliers such as packaging, transport, labeling, promotions in the shops, etc. Besides, the supermarkets indicate the price and have flexibility because they do not have to produce. From the view of producers there are two important perspectives. From the first perspective it is difficult to get benefits from this strategy. In the long run, producers could be trapped in these relationships. The price is defined by the supermarket while the producers must incur increasing costs to meet new requirements. The producers must invest in human capital (such as training in business and technical skills), quality control infrastructure, business information, cold storage facilities (GARCIA, POOLE, 2004). On the other side, in the short run, producers must acquire technical knowledge in order to meet it is an opportunity for them to acquire knowledge. In the long run, producer could use this knowledge for expanding their activities to new markets.

The European Union is the main market for Brazilian mango and grapes and the main requirements are the agrochemical analysis and certificates public and privates. One of the most important certificates is the EurepGAP. The European Union accounts for $73 \%$ of Brazilian grape exports and 69\% of Brazilian mango exports (SECEX - FOREIGN TRADE SECRETARIAT, 2005). The EurepGAP was created in 1997 by a group of British and Dutch retailers called Eurep (Euro- 
Retailer Produce Working Group). The group is composed of agricultural producers, inputs and services industries. According to Eurep (2005) EurepGAP "is a set of normative documents suitable to be accredited to internationally recognised certification criteria such as ISO GUIDE 65 and internationally recognised". The objective is "to reduce the risks in the agricultural production". One of the duties of the Group is to transfer knowledge about production techniques to farmers and there is a commitment to continuous improvement in order to deal with emerging issues. It is also important the fact that retail sector has been increasing the food imports from different countries and it is fundamental to know the origin of fruits and vegetables, the production conditions in order to guarantee food safety and sustainable production systems.

The main principles of EurepGAP certification are: (a) Food safety: derived from HACCP principles; (b) environmental protection: standards refer to diminishing the negative (c) effects of Agricultural production on the environment; (d) Occupational heath, welfare and society: standards refer to the activities on a farm and the conditions of workers;(e) animal welfare (where applicable).

The certificate is granted to single producers and group of producers organized in associations or cooperatives (BUREAU VERITAS, 2005). The members of Fruits and Vegetables EurepGAP are composed of retail and food service members, suppliers and associates.

\section{The Petrolina-Juazeiro Region (PJ)}

The São Francisco Valley region, more specifically the Petrolina-Juazeiro Region (PJ), offers favorable conditions for irrigated agricultural activity, thus configuring one of the largest fresh fruit exporting regions in Brazil. The irrigated area, with a predominance of fruit in this region, covers 120 thousand hectares and, among the main agricultural activities, the mango and grape farming can be pointed out. In the grape and mango production, the Sao Francisco Valley can be detached, where the greatest mango and grape producers in the country can be found. The area farmed with table grape in the region rose by $71.8 \%$ in the 1991/1995 period, which expanded the cultivated area from 2,620 hectares to approximately 4,500 hectares. The production increased from 1,050 tons to about 12,500 tons, which led to an increase in exports, generating 18,000 direct jobs (VALEXPORT, 2005). From 1997 to 2004, the participation of the Sao Francisco Valley region in the mango and grape production underwent very few alterations in terms of exported volume (in tons). In 1997, the Region accounted for $100 \%$ of the grape exports from Brazil and in 2004 this proportion was $98 \%$. Concerning mangoes, the participation vary from 98\% in 1997, to 92\% in 2004 (VALEXPORT, 2005). 


\subsection{The history of São Francisco Valley}

In the 50s, there were huge public and private investments in the Sao Francisco Valley where is located P-J region. Studies of the natural resources in the region were initiated at that time. All this work involve many activities such as the analysis of the soil to see the perspectives for irrigation projects, investigating the most suitable crops, the size of properties and the best way to manage the water supply. Furthermore, there were investments in infrastructure of transport, energy and urban and irrigation structure (GAMA SILVA, 2001).

In the 60s, the Federal Government created two irrigation projects called Mandacaru and Bebedouro. Both projects involve the expropriation of 500 hectares of land. In these projects were settled about 200 producers, 100 in each one. A centre of agricultural research was installed in each project in order to test a varied of crops. The main idea is to find out the characteristics of development of each crop and its adaptability to the regions conditions. The introduction of these projects was fundamental to initiating a learning process for all agents involved. In the next decade, there was an extension of the project and the creation of other institution, the Codevasf - the Federal Government Agency. The Codevasf was responsible for all execution of the irrigation project. From the studies of technical and economic feasibility to the activities involving many agents from different sectors including the participation of private firms. The Codevasf implemented 6 irrigation projects. Each project was composed of pieces of land from 6 to 200 hectares, about 38.000 hectares was distributed between medium and small producers. The Company supplied producers with the irrigation structure, land and water subsidies (DAMIANI, 1999; GOMES, 2004).

Table 1. Size of properties: large, small and medium producers.

\begin{tabular}{ll}
\hline \multicolumn{1}{c}{ Kind of producers } & \multicolumn{1}{c}{ Size of properties (hectare) } \\
\hline Small producers & Less or equal 12 hectares irrigable \\
Medium producers & Between 13 and 40 hectare irrigable \\
Large producers & From 41 hectares irrigable \\
\hline
\end{tabular}

Source: Embrapa, 2005.

According to Gomes (2004), small producers held, in 1980, $80 \%$ of the projects land. This percentage was decreasing and it fell to $60 \%$ in 1996. The small producers were replaced by medium producers who increase the size of their properties and to diversify the production. According to Leite et al (2005) about $70 \%$ of mangoes and $60 \%$ of grapes are produced by small producers in the husbandry structure.

The first export initiative was carried out in 1986 by melon producers. However, there were problems related to the quality of the fruit in the external market. In the 
beginning most exports were done by Cotia. Cotia was a cooperative composed of Japanese immigrants which was created in the 20s. The cooperative made an agreement with Codevasf and about 30 cooperative producers were settled in one of the irrigation projects. The Cotia had an export office located in Rotterdam, the Netherlands, which was responsible for negotiating and distributing melons and other fruits from it members in Europe. After a great success there was an increasing of the number of melon producers and the exports. Nevertheless the marketing channel of the new melon exporters was not the Cotia one and thus starting the quality problems. The problem was the image of the Brazilian melon was affected in the external market which had negative impact on Brazilian melon exports. It points out that fruits in the external market are recognizable by the country of origin.

This experience showed the importance of collective action of producers in order to guarantee a quality pattern. In these terms, the objective was to create an association to solve the quality problems (DAMIANI, 1999; GOMES, 2004). According to Damiani (1999) the function of the Cooperative was fundamental in the learning process in PJ. Their members were responsible for spreading the Cotia production techniques for external and internal market. The Cotia participated in the negotiation and the coordination of grape small producers for exporting collectively through an organisation called Brazilian Grapes Marketing Board BGMB (which changes from BGMB to BGMA - association instead of board).

In the 1987, there was the first mango and grape export. This time the producers had already the melon experience and they were more prepared in technical and commercial terms. One of the problems detected by producers in the beginning was the lack of agents to centralize the exports actions in the Region, such as the presence of associations and cooperatives (SILVA, 2001). In 1988 , the association of producers was created, the Valexport. The association received financial support in its early years from Codevasf and professional support from Cotia (DAMIANI, 1999).

In addition to Codevasf, Cotia, Valexport there is another institution which has been performing a great function in the region, the Embrapa - The Brazilian Agricultural Research Corporation. This was created in 1976 and its action was fundamental in adapting the right variety of mango and grape according to the climate and soil conditions of the region.

The main varieties of grape and mango come from the South and the Southeast of Brazil. The Embrapa had to develop new techniques of cultivation in order to adjust the plants to the new conditions. Besides, it was fundamental to produce in periods when Brazil could enter into the external market. The techniques of floral induction developed by Embrapa were essential to producing at the right period according to the market demands. Furthermore, the Embrapa has undertaken an important function in the Integrated Fruit Production System (IFP) program. The IFP is explained in detail in item 6. 
Two of the main associations in the PJ are Valexport and BGMA. Valexport is responsible for $70 \%$ of the total PJ fruit production and $80 \%$ of total fresh fruit exports. Specifically for mango, the Valexport members accounted for $60 \%$ of exports (Valexport, 2005). The BGMA is composed of 130 producers. The association is responsible for $65 \%$ of PJ grape exports. Its main responsibilities are to negotiate the transport (by air or sea) to Europe or other markets and to buy all the inputs for grapes production. The field research shows that the cost of transport by sea of a kilo of grapes is US\$ 0,19 (American dollar) and the same cost for a company from PJ, who is negotiating individually, is US\$ 1.20. In Brazil, there are some studies about the PJ region development features and the export activities (BARROS, COSTA \& SAMPAIO, 2004; LACERDA \& LACERDA, 2004; GAMA SILVA, 2001; OLIVEIRA FILHO, COSTA \& XAVIER, 2008; SAMPAIO, 2007; CACCIAMALI et al, 2006). However, in this study the field research was conducted also with European buyers and it was possible to identify the main requirements and investigate the actions done in PJ in order to meet them.

\section{Integrated fruit production and the mango and grape cases}

The integrated fruit production system (IFP) arose in Europe in the 1970s, aiming at the integrated pest control in the farms so that the use of pesticides could be diminished. The IFP allows tracking production, providing the producer with a certification seal and the exporter with quality fruit (VITTI \& CINTRA, 2003). The IFP is a holistic program based in four points. The organization of production structure, the sustainability of the system, the monitoring of process and information. This production system aims at the production of high quality food resulting from the use of techniques that take into consideration the environmental impacts on the soil, the water and crop system, allowing to evaluate the quality of the products, considering the physical, chemical and biological characteristics of the local natural resources in the processes involved in the productive chain. The main importance of program is to have a succession of steps defining to producers how to meet the external requirements. The adoption of IFP allows the traceability of the fruit, the integrated control of pests and diseases as well as the certification indicating compliance with Integrated Production. The application of IFP depends on change in mentality on the part of the producers involved, which requires a multidisciplinary team to make the Program possible. The IFP emerges as an answer to the consumer trends which present a greater concern about food safety and the use of production techniques that promote environmental sustainability. In 2006, there were 17 crops in Brazil being produced according to the new system. Nevertheless, only apples count on certified integrated production; mangoes and grapes produced 
in the Petrolina- PE and Juazeiro - BA regions have their processes close to obtaining the certification (ANDRIGUETO \& KOSOSKI, 2005). There are some steps in meeting all IFP requirements. These steps were defined according to standards of innovation and efficiently. The first step is to transfer to the producer knowledge about the IFP principles. At this level producers must be totally conscious about the principles of IFP. Secondly, producers must meet the principles of Good Agricultural Practices (GAP). In the next step, producers must meet the HACCP (hazard analysis and critical control point) and GAP principles. Follow the EurepGap principles and finally the IFP certificate. Therefore, producers must meet the requirements of GAP, HACCP and EurepGap in order to get the IFP certificate. Those producers who join the integrated fruit production system receive an affiliation credential to the cultivation system and compromise in abiding by the production regulation established by the norms, as well as in submitting to specific inspections and technical control. Furthermore, producers must adopt a single way for documenting field reports related to crop and phytosanitary operations performed in their properties, as was established for the product, called "field notebook". It should be pointed out that producers must also attend government certified formation courses on integrated production, or belong to associations or organisms counting on qualified technical personnel. Complying with the specifications presented, the producer can use the integrated production certificate (EMBRAPA, 2002).

The introduction of IFP in the PJ can be divided in two periods. In the first period the project trained mainly large mango and grape producers. The Embrapa unit in the city of Petrolina - PE was very active in that period and worked towards raising awareness of the local producers training specialized technical personnel in the area who guide producers. The second period started in 2003 and it involves an agreement between Embrapa; the Brazilian Micro and Small business Support Service - Sebrae; Ministry of Agriculture, Livestock and Food Supply - MAPA and Nilo Coelho Irrigation District. The main objective is to widen the program to include small producers. Medium producers could participate if they are members of associations or cooperatives. In this second period the project is composed of three elements: training, technology and commercialization. In other words the main idea of this project is to transfer to small and medium producers the benefits of IFP standards such as the reduction of agrochemical costs, the organization of production activities, the control of production systems through field notebook, training about pest control and floral induction in order to be able to plan harvest and to get certificates.

Two agronomic engineers and eight agricultural technicians were hired to undertake the training of producers. These agricultural technicians visit the properties every week to teach production techniques to small farmers and evaluate the field notebook according to IFP standards. The agricultural technicians teach producers how to improve the system and infrastructure 
on the farm to meet IFP requirements such as storage conditions and use of agrochemicals. Besides the agronomic engineers organize and give training about EurepGap certificate. The main idea is to show to producers the requirements of the certificate and how to meet these requirements in the property. The training is elaborated according to the reality and necessities of small properties. In the meantime producers receive information about how to get the certification and the financial support for this. As a whole the certification process takes three years and the project pays $50 \%$ of the total cost involved. In addition to this, producers have the opportunity to use a palm top computer instead of a field notebook. In this case, producers can get financial support from the project. About $50 \%$ of total costs to replace the traditional field notebook with palm top are paid by the project and the other half is paid by producers.

\section{The description of relationships between PJ producers and European Buyers}

The relationships between mango and grape producers from PJ and European buyers can be classified in: vertical integration, consignment-selected firm, consignment - trust relationship and consignment basis. In the vertical integration the producers commercialize their fruits themselves. Producers have commercialization offices located in Rotterdam, in the Netherlands. They are responsible for all activities from production to deliver them to wholesalers and retailers in European countries. According to producers, the main argument in favour of hierarchical relationship is to the closeness to the consumption market. Fruits are highly perishable and it is important to understand how the market works in order to obtain competitive advantage. Some of these producers are negotiating directly with German retailers and they have wide understanding of the preferences of different markets. They are undertaking the functional and inter-sector upgrading. In the consignment basis producers hire one firm (or more) to commercialize theirs fruits in Europe. The firm receives a commission which could vary from $7 \%$ to $10 \%$ of total sales. They have no long term relationships which mean that European firm transfers to producers just the information about the standards of fruits. There is no commitment between them, which means an arms' length relationship. This kind of relationship is predominantly between mango exporters, mainly the ones which do not have certificates. In the relationship called consignment-selected firm producers are represented by a firm in the external market and a contract is established and signed by both parties. When the first shipment of the season arrives in Europe the firm verifies the quality standards of fruits. If the fruits meet the standards, the firm pays producers for the production in that season. This part of payment is less than $50 \%$ of the total payment for the season. This firm is responsible for commercializing the fruits and to transfer to producers all knowledge 
about market preferences and tendencies as well as the knowledge about new standards and how to meet them. Despite the fact that the relationship is closer than a consignment basis, the firm receives a commission for its services from $7 \%$ to $10 \%$. At last, there is the consignment - trust relationship which involves long term links (about 10 years in some cases) and high frequency. The higher frequency in the accomplishment of a relationship also helps the involved agents to have better knowledge of each other. In this situation, the firm transfers to producer knowledge about production techniques, preferences of market, and tendencies and it also receives a commission which could vary from $7 \%$ to $10 \%$.

\section{Discussion of results}

Since the first export experience with melon, the producers on the region were awake of the importance for exporting in group. The experience in PJ shows that members of a cooperative or association can reduce the transport costs to Europe and to buy inputs in group which reduce the prices paid. They also can obtain technical capability trough their relations with buyers and more information about the preferences of the market.

In terms of institutions, Embrapa is responsible for transferring knowledge about production techniques to producers. Valexport is responsible for organizing the producers in order to be represented in the Government. Cotia was responsible for spreading the knowledge about production techniques. Their members were prepared for meeting the standards from global market and they were aware of the importance of collective action. More recently, the IFP program expanded for small producers due the agreement between Sebrae, Embrapa, and Mapa. Besides the Senador Nilo Coelho Irrigation District has been supporting the producer initiatives to meet the requirements of the global market. Also, the PJ history and its learning process are fundamental for the development of the region. Finally, the different kind of relationships between PJ producers and European buyers indicate the sort of knowledge transferred to producers in these transactions.

According to the GVC approach the producers of PJ have been undertaking different types of upgrading. Firstly, the product and process upgrading resulted from technical capability acquired in their relations with external agents, such as buyers and institutions. Secondly, some of PJ producers have got commercialization offices in Rotterdam which are responsible for negotiating their sales. In this case they are acquiring knowledge about consumer markets and marketing channels and are undertaking functional and inter-sector upgrading. This kind of upgrading is so important because producers can learn with this process and to acquire knowledge about market preferences and the dynamic of channels marketing in Europe. 


\section{Conclusions}

The objective of this paper is to identify some elements which contribute to the entry of small and medium producers into the global market. The categories of analysis considered on this study are: the routines for acquiring capabilities, path dependency which is related to the learning process of the organization and the history of organization, and the environment which refers to the links to institutions and other agents.

The grape and mango producers in PJ have been meeting the supermarket requirements and there are some institutions which are so important for supporting their activities. The experience of PJ shows the importance of institutions such as Cotia and BGMA for the learning process of producers and their entry into the global market and how is important the interactions in the group for obtaining knowledge about production techniques and consequently for reaching export markets. The BGMA, which is most composed of small and medium producers, is responsible for $65 \%$ of PJ grape exports. In the case of PJ, the producers acquire capabilities for meeting the requirements of the external market through interactions with institutions, other producers and buyers. The main institutions are Embrapa, Codevasf, Sebrae. They are undertaking product and process upgrading obtained due technical capability and functional and inter-sector upgrading acquired from market capabilities.

Regarding managerial implications the experience of PJ shows the importance for producers to develop closing and long term relationships with buyers in order to obtain more technical and market capabilities. For buyers it is also important this kind of relationship because they can guarantee an increase of range, quality and seasonal availability of fresh fruits. Besides, the experience of BGMA shows the importance of reducing transport costs for exports to Europe as an important competitive advantage for their members. The experience of PJ shows the importance of different kind of institutions involved in the process of development and how is essential the action of the government providing infrastructure for associations and cooperatives initiatives in order to guarantee their competitiveness in the external market.

\section{References}

ANDRIGUETO, J.R.; KOSOSKI, A.R. Desenvolvimento e conquistas da produção integrada de frutas no Brasil - até 2004, Ministry of Agriculture, Cattle Breeding and Supply - MAPA, Programa de desenvolvimento da Fruticultura - Profruta. Disponível em: www.agricultura.gov.br Acesso em: Abril 2005.

BUREAU VERITAS. Certificação EurepGap. Disponível em: www.bureauveritas. com.br Acesso em: Jan. 2005. 
CACCIAMALI, M.C.; SANTOS, S.B.S.; JOSÉ-SILVA, M.F.; TATEI, F. Configuração e inserção no mercado internacional de dois sistemas produtivos locais: a experiência dos agrupamentos vitícolas de Petrolina (Brasil) e Tierra Amarilla (Chile). Revista Econômica do Nordeste, v.37, p.167-186, 2006.

DAMIANI, O. Beyond market failures: irrigation, the State, and Non-traditional Agriculture in Notheast Brazil. Tese-Department of Urban Studies, Massachusetts Institute of Technology - MIT, Boston, 130 p, 1999.

DAVID, P.A. Path dependence - a foundational concept for historical social science. Cliometrica, v.1, n.2, Summer 2007.

DOLAN, C.; HUMPHREY, J. Governance and trade in fresh vegetables: the impact of UK supermarkets on the African horticulture industry. Journal of Development Studies, Vol.37, n.2, pp. 1-37, 2000.

EISENHARDT, K.M. Building theories from case study research. Academy of Management Review, v.14, n.4, pp.532-550, 1989.

EMBRAPA - The Brazilian Agricultural Research Corporation. Produção Integrada de Frutas, Brasília, 2002. Disponível em: www.cnpma.embrapa.br Acesso em: Jan.2005.

EMBRAPA - The Brazilian Agricultural Research Corporation. Sistemas de Produção, Brasília, 2005. Disponível em: www.cnpma.embrapa.br Acesso em: Jan. 2005.

GAMA SILVA, P.C.G. Articulação dos interesses públicos e privados no pólo Petrolina - PE/Juazeiro - BA: em busca de espaço no mercado globalizado de frutas frescas. Tese, Instituto de Economia, Universidade Estadual de Campinas - UNICAMP, 239 p., 2001

GARCIA, M.; POOLE, N. The impact of private safety and quality standards for fresh produce exports from Mediterranean countries. London : Food Industry Management Unit, Department of Agricultural Sciences, Imperial College, University of London. Disponível em: www.imperial.ac.uk/agriculturalsciences/cfcr/ Acesso em: Jul. 2004.

GEREFFI, G. Competitividade e redes na cadeia produtiva do vestuário na América do Norte', Revista Latino-americana de Estudos do Trabalho, ano 4, n.6, pp. 101-127, 1998.

GEREFFI, G. International trade and industrial upgrading in the apparel commodity chain. Journal of International Economics, Vol.48, pp.37-70, 1999.

GOMES, R. Farming for supermarkets: its collective good problems and what Brazilian growers have done about them. Tese - Department of Urban Studies and Planning, Massachusetts Institute of Technology (MIT), 180 p., 2004. 
HUMPHREY, J.; SCHMITZ, H. Governance and upgrading: linking industrial cluster and global value chain research. IDS Working Paper 120, Institute of Development Studies, University of Sussex, 30p, 2000.

HUMPHREY, J.; SCHMITZ, H. Governance in global value chains. IDS Bulletin 32.3, Institute of Development Studies, University of Sussex, 16 p., 2001.

KAPLINSKY, R.; MORRIS, M. Handbook for value chain research, Mimeo. Institute of Development Studies, 2001. Disponível em: www.ids.ac.uk Acesso em: Jun. 2004.

LACERDA, M.A.D.; LACERDA, R.D. O cluster da fruticultura no Pólo Petrolina/ Juazeiro, Revista de Biologia e Ciências da Terra, v.4, n.001, Campina Grande, PB, 2004.

LALL, S. Technological capabilities and industrialization. World Development, v.2, n.20, p.165-186, February, 1992.

LAZZARINI, S.G. et al. Integrating supply chain and network analyses: the study of netchains. Journal on Chain and Network Science. v.1,n.1, p. 7-22, 2001.

LEITE, E.M. et al. Agricultura familiar e sustentabilidade - implantação do sistema de produção integrada de frutas. Relatório do Distrito de Irrigação Senador Nilo Coelho, 2005.

LUNDVALL, B. A. National systems of innovation: towards a theory of innovation and interactive learning. Welington House, London, 1992.

OLIVEIRA FILHO, S.F.S.; COSTA, E.F.; XAVIER, L.F. Diversificaçã̃o da produção e acesso a mercados: estudo de caso para a fruticultura irrigada do Pólo Petrolina-Juazeiro, Disponível em: http://www.sober.org.br/palestra/9/266.pdf Acesso em: Nov. 2008.

REARDON, T. et al, The rise of supermarkets in Africa, Asia, and Latin America. American Journal Agricultural Economics, v. 85, n.5, pp.1140-1146, 2003.

SAMPAIO, L; M. B. Modelo Principal-Agente para contratos entre pequenos produtores e empresa exportadora de manga no Rio Grande do Norte. Rev. Econ. Soc. Rural, v. 45, p. 879-898, 2007.

SAUVÉE, L. Strategic interdependence and governance: empirical evidence with two agri-food networks in the fresh and processed vegetable sectors in France. In: III Congresso Internacional de Economia e Gestão de Negócios Agroalimentares, 2001, Ribeirão Preto. Anais... Ribeirão Preto : PENSA, 2001.

SCHMITZ, H. Responding to global competitive pressurre: local co-operation and upgrading in the Sinos Valley, Brazil', IDS Working Paper 82, Institute of Development Studies, UK, 1998. 
SCHMITZ, H.; KNORRINGA, P. Learning from global buyers. Journal of Development Studies, v.37, n.2, p.177-205, 2000.

SECEX - FOREIGN TRADE SECRETARIAT. Estatísticas. Disponível em: www. secex.gov.br Acesso em: Jun. 2005.

TEECE, D.; PISANO, G. The dynamic capabilities of firms: an introduction, University Press, Oxford, 1994.

TEECE, D.; PISANO, G.; SHUEN, A. Dynamic capabilities and strategic management. Strategic Management Journal, v. 18, n.7, pp.509-533, 1997.

VALEXPORT - Associação dos Produtores Exportadores de Hortigranjeiros e Derivados do Vale do São Francisco. Potencial Frutícola do Vale do São Francisco, Apresentação, Petrolina, 2005.

VITTI, A.; CINTRA, R. Certificação: o caminho para a qualidade. Hortifruti Brasil, v.1, n.11, pp.8-11, 2003.

VORLEY, B. Corporate Concentration from farm to consumer. UK Food Group, 2003. Disponível em: www.ukfg.org Acesso em: Fev. 2005

WINTER, S.G. Understanding dynamic capabilities. Working paper Series 2002 -05 of the Reginald H. Jones Center, The Wharton School, Nov. 2002.

YIN, R.K. Estudo de caso - planejamento e métodos, Bookman, Porto Alegre, 2001.

ZYLBERSZTAJN, D.; NADALINI, L.B. Explaining agro-industrial contract breaches: the case of Brazilian tomatoes processing industry. Rev. Econ. Soc. Rural, v.45, n.4, Brasília, out./dez. 2007. 